\title{
Populismo \& Preconceito: Clarificando Questões Ideológicas e Jurídicas de um Vírus Político, em diálogo com Umberto Eco
}

\section{Populism \& Prejudice: Clarifying Ideological Issues and Legal Policy Virus, in dialogue with UMBERTO ECO}

\section{Populismo Y Prejuicio: Aclarando Problemas Ideológicos y Virus de Política Legal, en DiÁLOGO CON UMBERTO ECO}

Paulo Ferreira da Cunha*

\begin{abstract}
$1 \mathrm{Um}$ pleno de preconceitos em ação. 2 Eterno retorno dos preconceitos. 3 Os catorze tópicos de Umberto Eco. 3.1 Tradição e massificação. 3.2 Irracionalismo, recusa da modernidade e do iluminismo. 3.3 Culto da ação, anti-intelectualismo. 3.4 Unanimismo. 3.5 Medo da diferença. 3.6 Fruto da frustração. 3.7 Nacionalismo e teoria da conspiração (inter)nacional. $3.8 \mathrm{O}$ inimigo é forte e é fraco. 3.9 Exaltação da guerra. 3.10 Elitismo de massas. 3.11 Pseudoheroicidade e pseudomartírio do militante comum. 3.12 Ersatz da guerra: sexismos. 3.13 Populismo, antiparlamentarismo. 3.14 Uma novilíngua. 4 Brevíssima conclusão jurídico-sociológica. Referências.
\end{abstract}

\section{RESUMO}

Objetivo: O objetivo do presente artigo é fazer uma arqueologia do sentido profundo do populismo e entidades a ele associadas, procurando identificar alguns traços mais ou menos perenes dessa realidade psicológica, social, e política, com importantes

\footnotetext{
Juiz Conselheiro do Supremo Tribunal de Justiça. Catedrático da Faculdade de Direito da Universidade do Porto (suspenso devido ao exercício daquele primeiro cargo). Faculdade de Direito da Universidade do Porto, (FDUP) - Porto, Portugal. E-mail: <lusofilias@gmail.com>. http://orcid.org/0000-0002-3602-8502
} 
Populismo \& preconceito: clarificando questões ideológicas e jurídicas de um vírus político, em diálogo com Umberto Eco

consequências jurídicas.

Metodologia: Este trabalho foi desenvolvido por meios dedutivos, com base em aportações bibliográficas pós-disciplinares (no sentido de Gonçal Mayos e sua escola) oriunda essencialmente dos campos da Psicologia Social e da Sociologia, da História das Ideias Políticas, etc., visando de forma estruturada carrear os conhecimentos multiplamente centrados epistemicamente para a indagação. Seguiu-se explicitamente a contribuição do semiólogo italiano do maior renome internacional Umberto Eco.

Resultados: Apesar de haver juristas que consideram tabu temas que possam ser mais polémicos politicamente, e talvez mais ainda social e civilizacionalmente, remetendo-se a uma "castidade metódica" tecnicista, quer a questão do preconceito quer a do fascismo são, não apenas desafios sócio-políticos inafastáveis nos tempos que correm, como colocam objetivamente questões às quais os juristas se não podem furtar. Questões de efetivação real de Direitos Humanos e direitos tout court, e questões da própria sobrevivência dos Estados democráticos de direito, ou seja, questões absolutamente constitucionais e das mais importantes. Concluiu-se, preliminarmente, que é fundamental discutir preconceito e fascismo.

Contribuições: Neste artigo, em diálogo com Umberto Eco, um autor cujas teses estão agora internacionalmente a ser revisitadas, avançamos uma análise que parte da tese de que o fascismo é a apoteose dos preconceitos clássicos, antigos, tradicionais. E que obviamente ele não é apenas uma ideologia historicamente situada, ou somente um período localizado na história da Italiano do séc. XX. Se nos repugna dizer que ele é eterno, é certo que tem avatares que sempre retornam. Há um "eterno retorno" do fascismo, com vestes diferentes, mas com traços comuns. E seria estulto e suicida que as democracias, e os juristas democratas não vissem que esse é, aqui e agora, o grande perigo que ameaça o nosso comum modo de viver e progredir: o Estado Constitucional. Em cada um dos tópicos que retomam a perspetiva de Eco se avançam contribuições matizadoras ou aprofundamentos.

Palavras-chave: Preconceito. Populismo. Autoritarismo. Fascismo. Totalitarismo. Umberto Eco.

\section{ABSTRACT}

Objective: The purpose of this article is to carry out an archeological investigation of the profound meaning of populism and associated entities, seeking to identify some fairly 
perennial traits of this psychological, social, and political reality, with important legal consequences.

Methodology: This work was developed by deductive methods, based on postdisciplinary bibliographic contributions (in the sense applyed by Gonçal Mayos and his school) originating essentially from the fields of Social Psychology and Sociology, the History of Political Ideas, etc., aiming to assemble the epistemically multipleally centered knowledges in a structured way for the inquiry. The contribution of the Italian semiologist from the highest international renown Umberto Eco was explicitly followed.

Results: Although there are jurists who consider subjects that may be more politically, and perhaps even more socially and civilizationally controversial taboo, employing a technicist "methodical chastity", both the issue of prejudice and that of fascism are not only unavoidable socio-political challenges in these times, but objectively pose questions to which jurists cannot evade. Issues of real effectiveness of Human Rights and tout court rights, and issues of the very survival of Democratic States of Law, that is, absolutely constitutional and the most important issues. It was concluded, preliminarily, that it is fundamental to discuss prejudice and fascism.

Contributions: In this article, in dialogue with Umberto Eco, an author whose theses are now being internationally revisited, we advance an analysis that starts from the thesis that fascism is the apotheosis of classic, ancient, traditional prejudices. And that it obviously is not just a historically situated ideology, or just a period located in the history of Italian in the 20th century. If it disgusts us to say that it is eternal, it is certain that there are avatars that always come back. There is an "eternal return" of fascism, with different robes, but with common traits. And it would be unwise and suicidal for democracies and democratic jurists not to see that this is, here and now, the great danger that threatens our common way of living and progressing: the Constitutional State. In each of the topics that take up the perspective of Eco, there are advancing nuances or deepening contributions.

Keywords: Prejudice. Populism. Authoritarianism. Fascism. Totalitarianism. Umberto Eco.

\section{RESUMEN}

Objetivo: El objetivo de este artículo es hacer una arqueología del significado profundo del populismo y sus entidades asociadas, buscando identificar algunos rasgos más o 
Populismo \& preconceito: clarificando questões ideológicas e jurídicas de um vírus político, em diálogo com Umberto Eco

menos perennes de esta realidad psicológica, social y política, con importantes consecuencias legales.

Metodología: Este trabajo se desarrolló por vía deductiva, a partir de aportes bibliográficos posdisciplinares (en el sentido de Gonçal Mayos y su escuela) originados fundamentalmente en los campos de la Psicología Social y Sociología, la Historia de las Ideas Políticas, etc., con el objetivo de forma estructurada de trasladar el conocimiento epistémicamente centrado para la indagación. Se siguió explícitamente la contribución del semiólogo italiano de mayor renombre internacional Umberto Eco.

Resultados: Si bien hay juristas que consideran temas tabú que pueden ser más polémicos políticamente, y quizás incluso más social y civilizatoriamente, refiriéndose a una "castidad metódica" tecnicista, tanto el tema del prejuicio como el del fascismo no son solo desafíos socio-insondables. políticos en estos tiempos, ya que objetivamente plantean cuestiones que los juristas no pueden evitar. Cuestiones de efectividad real de los Derechos Humanos y derechos tout court, y cuestiones de la propia supervivencia de los estados democráticos de derecho, es decir, absolutamente constitucionales y las cuestiones más importantes. Se concluyó, preliminarmente, que es fundamental discutir el prejuicio y el fascismo.

Contribuciones: En este artículo, en diálogo con Umberto Eco, autor cuyas tesis ahora se revisan internacionalmente, avanzamos un análisis que parte de la tesis de que el fascismo es la apoteosis de prejuicios clásicos, antiguos, tradicionales. Y eso, obviamente, no es solo una ideología históricamente situada, o solo un período ubicado en la historia de Italia en el siglo XIX. XX. Si nos disgusta decir que es eterno, es cierto que tiene avatares que siempre regresan. Hay un "eterno retorno" del fascismo, con vestimenta diferente, pero con rasgos comunes. Y sería estúpido y suicida si las democracias, y los juristas demócratas, no vieran que este es, aquí y ahora, el gran peligro que amenaza nuestra forma común de vivir y progresar: el Estado Constitucional. En cada uno de los temas que vuelven a la perspectiva de Eco, se avanzan aportes de matices o profundización.

Palabras clave: Prejuicio. Populismo. Autoritarismo. Fascismo. Totalitarismo. Umberto Eco.

"Seria tão confortável para nós se alguém assomasse à cena do mundo e dissesse: 'Quero reabrir Auschwitz, quero que as camisas negras tornem a desfilar em parada pelas praças italianas!' Mas ai, a vida não é tão fácil. O UrFascismo ainda pode voltar sob as vestes mais inocentes. $\mathrm{O}$ nosso dever é desmascará-lo e apontar a dedo cada uma das suas novas formas - diariamente, em todo o mundo." (ECO, 2016, p. 39). 


\section{UM PLENO DE PRECONCEITOS EM AÇÃO}

É verdade que, como disse Norberto Bobbio, não será fácil a ninguém atirar a primeira pedra, considerando-se absolutamente limpo de preconceitos ou acima deles. Todos, mais ou menos, terão, frequentemente, sem se aperceberem, estes ou aqueles preconceitos.

Há de se fazer um esforço para superá-los, mas se essa é uma tarefa de uma "arte de ser flexível” (RISO, 2018), que se pode ir cultivando com o amadurecimento, a leitura e as viagens (e o fazer amigos entre pessoas diferentes), como recomendou alguém, há quem exagere e faça do preconceito programa de vida e credo, como que religioso, e com fanatismo que vem do fundo da alma.

Há, na verdade, pessoas que fazem o pleno dos preconceitos mais clássicos, assumindo em si um máximo de teias de aranha ideológicas e de cosmovisão ou mundividência: são social (e simbolicamente) classistas (pela "distinção" de classes, pela segregação, pelo evitamento social e, por vezes, pelo esnobismo (CLINCHAMPS, 1964) etc.), politicamente anticomunistas (e antissocialistas, ou social-democratas, trabalhistas etc. - chegam a ser antidemocratas-cristãos), antidemocráticos (antirrepublicanos, antipluralistas, anti Direitos Humanos), anti(vetero)liberais, antiparlamentares (esta última seria a tríade ideológica que, segundo os documentos preliminares, deveria ter presidido à Constituição do Estado Novo português - mas que nem a própria Constituição de 1933 conseguiu plenamente concretizar ${ }^{1}$ ), religiosamente antimodernos (por exemplo, entre os católicos, contra o Concílio Vaticano II e obviamente contra o Papa Francisco), antissindicais, antimaçônicos, anticultura moderna hoc sensu (que consideram "degenerada", por exemplo, desde o Cubismo ou o Surrealismo ao Jazz), nacionalistas, xenófobos, etnocêntricos, racistas, misóginos e homofóbicos.

No entanto, há alguns que, eventualmente tendo um pouco de cada um desses preconceitos, dão mais relevo a um ou a outro, deixando os demais um pouco na penumbra, pelo exagerado avolumar de um ou outro entre eles.

Não é necessário possuir (ou estar possuído de) todos esses preconceitos em altíssimo grau para se poder considerar que o seu portador (e mais ainda o seu ativista) é um fascista.

Caso o direcionamento dessas ideias siga a linha da expressão mais souple “populista”, já que a expressão "fascista” é ,em vastos meios ,ainda muito "politicamente

\footnotetext{
${ }^{1}$ Cf. o nosso Raizes da República. Introdução Histórica ao Direito Constitucional (CUNHA, 2006, p. 363 ss.).
} 
Populismo \& preconceito: clarificando questões ideológicas e jurídicas de um vírus político, em diálogo com Umberto Eco

incorreta" ${ }^{2}$, chegaremos à idêntica situação: para ser populista, aliás, até bastariam menos "pontos" na escala dos preconceitos. O fascista é um populista elevado a uma potenciação de preconceito muito alta. Embora não seja apenas o preconceito que o caracteriza, a sua ação violenta também concorda com a exacerbação do preconceito porque o fascista é muito consequente com o seu credo extremista: não é um mero crente, é praticante e militante.

É compreensível, então, que o fascista não se limita, pelo menos quando o momento é propício (como nos tempos desiludidos e críticos de hoje), a carpir mágoas dos seus traumas e das suas frustrações, a maldizer, nem sequer a escrever... $\mathrm{O}$ fascista age. Dir-se-ia que age (ou "dispara") antes mesmo de pensar - embora isso seja só meia verdade, porquanto há um pensamento que preside à sua ação: primário, mas um pensamento. A sua ação pode começar por mera distribuição da propaganda de anticorrupção contra os políticos, os deputados, a justiça... No que muitos estarão até de acordo, pelo menos levados pela demagogia, que lhes faz crer que se vive, em democracia, em um mundo da mais lamacenta corrupção. Nesse caso, logo se segue (ou lhe é concomitante) a vandalização de locais sagrados, o ataque a grupos vulneráveis e a seus bodes expiatórios ${ }^{3}$ preferidos. O céu (ou o inferno, no caso) é o limite.

\section{ETERNO RETORNO DOS PRECONCEITOS}

Assim como se pode falar do eterno retorno do fascismo, é óbvio que existe um eterno retorno do preconceito. De velhos preconceitos que, por vezes, voltam, em força, para novas gerações que não só viram os seus malefícios em ação no passado, por exemplo, mas também observaram os novos preconceitos.

Então, é notório que há sempre mais ou menos preconceitos (umas épocas e uns lugares são mais preconceituosos que outros), uns mais antigos e outros mais recentes,

\footnotetext{
${ }^{2}$ A expressão "fascista", martelada a torto e a direito em algumas situações revolucionárias e por alguns ativistas, com intuitos em grande medida estigmatizantes, ou mesmo insultuosos, adquiriu, infelizmente, para os que a utilizam, conotações muito "esquerdistas" ou esquerdizantes, pelo menos em alguns socioletos e ideoletos. Tal não deveria ocorrer. A expressão deveria ter um sentido muito mais denotativo (embora não se livrando, é certo, de algumas conotações, dado o seu histórico pathos). "Anti-fascista", aliás, também não deveria ser visto como uma marca ou estigma. Pode-se ser antifascista e democrata, mesmo sendo-se conservador, evidentemente. Veja-se apenas - para referir uma só figura - o exemplo do grande jurista, que chegou a ser presidente da União dos Juristas Católicos Italianos e era um dos maiores especialistas em Montesquieu, Sergio Cotta, resistente "partisan”, o qual não deixou de ser um espírito livre quando terminou a II Guerra. A defesa da democracia é, por definição, um grande denominador comum, que a todos compreende, excluindo apenas os que dela se excluem, os antidemocratas. Por isso, da direita à esquerda, há e houve, antifascistas.

${ }^{3}$ Sobre os bodes expiatórios, em geral, Girard (1982).
} 
assim como existem usos diversificados desses tipos-ideais clássicos.

A variedade do preconceito leva a paradoxos, como o de haver vítimas potenciais do preconceito que a ele aderem e que discriminam outras vítimas. Há, também, grupos que segregam e perseguem outros ou se envaidecem em excesso de identidades (por vezes, forçadas, tal como outrora se efabularam nacionalismos), o que é potencialmente perigoso e segregador. E, se agora, os obesos se enchessem de brios e desatassem a disparar contra quem meramente os olhasse na rua, desde logo? E a perseguir as elegâncias? E, se além destes, os fumadores o viessem a fazer? O grande problema dos identitarismos, dos orgulhos bairristas, de clube, de seita é o de serem narcisistas, por vezes, violentíssimos, de quem crê que uma característica qualquer, natural ou artificial, é realmente o caracterizador da sua essência e que essa essência é tão excelsa, tão melhor que as demais que, no limite, os que dela não partilham devem ser ou subjugados ou exterminados.

Tudo isso faz deste universo uma constelação um tanto caótica, em que o observador pode tentar adivinhar, mas certamente, em muitos casos, poderá errar, por fazer generalizações, que, de algum modo, espelham também algum preconceito...

$\mathrm{O}$ fato de haver preconceitos ligados a ideologias, a seitas, a religiões, a classes e a grupos sociais etc. acaba até por ser uma ajuda para orientação e entendimento nesta selva oscura. Será natural que uma pessoa sintonizada ou fanatizada por um grupo intolerante e extremista tenha preconceitos-tipo dessa linha. No entanto, pode surpreendentemente ocorrer que, normalmente, por razões pessoais (de história pessoal, vivência e, portanto, de autocomplacência ou de família etc. ou simplesmente por interesse) a pessoa "y" ou " $z$ " abra uma exceção para isto ou para aquilo, para este(s) ou aquele(s) no seu universo fechado de preconceito. Isso não fará dessa pessoa menos preconceituosa em geral, apenas pontualmente a mostrará um pouco mais humana ou com uma rede de contatos mais diversificada.

Isso ocorre, por exemplo, em grupos com regras bem definidas, mas sem meios muito eficazes de tutela ou sanção. É o caso de igrejas secularmente instituídas, que, ao contrário de seitas que, em geral, possuem poder fortíssimo de proximidade, não exercem, salvo em meios muito restritos, uma verdadeira coação de comportamentos (ao menos, exteriores) sobre os fiéis. Mesmo nos casos em que a exercem, é interessante verificar como ela acaba por especializar-se em certos tabus, pondo, pelo menos, entre parêntesis certos elementos de crença virtualmente impossíveis de controlar ou que poderiam acarretar consequências desagradáveis para o grupo.

Nessa perspectiva de análise, Umberto Eco (não é de agora, embora só agora se comece a evidenciar o interesse por publicar o seu opus magnum sobre o tema) aponta uma lista de características do Ur-Fascismo, espécie de Fascismo essencial, o que ele 
Populismo \& preconceito: clarificando questões ideológicas e jurídicas de um vírus político, em diálogo com Umberto Eco

chama, algo literariamente, de "eterno" (o que é talvez doirá-lo excessivamente - temos tendência a prezar as coisas eternas -, embora não seja essa a intenção do autor). Diferentemente disso, é o eterno retorno do fascismo (o que lhe dá, na verdade, alguma característica de eternidade), que inegavelmente existe (RIEMEN, 2012.). Está à vista...

\section{OS CATORZE TÓPICOS DE UMBERTO ECO}

Assim, há um rol de características que nos permitimos sintetizar e modelar, comentando (ECO, 2018; ECO, 2016, p. 25 ss.). De algum modo, o comentário que se seguirá constitui uma recensão crítica do texto de Umberto Eco, uma sua glosa. O que se vai ler, em seguida, acompanha, assim, pari passu, o texto de Eco e procura sintetizar o que diz em características que pretendemos mais universais (especialmente nos títulos dos vários tópicos), se possível. Visamos a dialogar com ele livremente, desde logo, de forma mais atualista e ligada com a nossa realidade. A fonte está revelada, mas não atribuímos ao seu original autor a culpa pelas nossas reflexões, pelos desenvolvimentos e pelas eventuais reticências (raras), aqui e ali

\subsection{TRADIÇÃO E MASSIFICAÇÃO}

Há, no fascismo, certo culto da tradição, mas comentemos: nem todo o tradicionalismo é fascista, como Eco adverte também, e pode haver tradicionalismo quase confundível com o liberalismo velho. É mais a velharia para dar alguma legitimidade que se cultua, uma tradição Kitsch. Realmente, pedida de empréstimo, porque o fascismo, de fato, é uma prole que, de si mesma, nasce e não tem outra mãe. Os fascistas podem tentar doirar-se com velhas mitologias germânicas, nórdicas, italianas, salazaristas etc., mas, no limite, só se têm a si mesmos. Cada vaga parece ser ainda mais desenraizada ${ }^{4}$ que a precedente. Por isso, sem dúvida os genuínos autores dos Estados Novos se revolvem nos túmulos perante alguns aprendizes de feiticeiro atuais.

Há uma diferença profunda entre a pose, apesar de tudo, juridista (formal) de alguns funcionários do Estado Novo português, por exemplo, e o terrorismo antijurídico da polícia política do mesmo regime (que uma mitologia popular dizia agir para além do próprio conhecimento do ditador - como um king can do no wrong, ou "a culpa é do cabido, não do bispo"). Ambas as realidades pertencem ao mesmo regime. Assim, também, fenômenos como o nacional-sindicalismo são fascistas, e Salazar nunca lhes terá dado relevo. Do mesmo modo, ainda, uma coisa é o viver habitualmente do dito

4 Sobre a temática essencial das raízes, enraizamento e desenraizamento, v. Weil (2014). 
Estado Novo e a barbárie dos campos de concentração nazis. A elegância do verbo escrito do ditador português e a sua timidez pública, em contraste com a fúria verbal de Hitler e Mussolini, não é o lugar para desfiar um rol de diferenças, nem de (mais ainda) semelhanças. Uma boa formação democrática permite a um cidadão de bem e com discernimento identificar imediatamente populismo e fascismo mesmo quando estão ainda no ovo. Ovo de serpente.

\subsection{IRRACIONALISMO, RECUSA DA MODERNIDADE E DO ILUMINISMO}

O fascista pode gostar de tecnologia e usá-la em seu proveito, mas não é pelo progresso, nem pela mentalidade moderna, e sim por um uso meramente instrumental. O ódio visceral à Revolução Francesa e ao que representa (desde logo, os valores de Liberdade, Igualdade, Fraternidade) é o que prevalece. A prevalência da tecnologia, o discurso de exaltação da máquina, da eficiência, do número - é sempre anti-humanista, mesmo que desacompanhado do enquadramento bárbaro desta ideologia. Sabemos que muitos técnicos e muitos tecnocratas não enxergam um palmo à frente da estrita técnica que dominam, quantas vezes, apenas pela repetição da prática ou pelo decorar da teoria. Conhecemos também que, como dizia um grande conhecedor da coisa pública e das artes e das malas artes políticas, Brito Camacho, a simples experiência não é ciência: pois o burro, toda a vida à roda da nora, tendo por isso uma grande vivência do círculo, não inventou a geometria...

\subsection{CULTO DA AÇÃO, ANTI-INTELECTUALISMO}

Res, non verba, poderia ser o lema, se se intelectualizasse. A ideia de que há uma prevalência ontológica (e quiçá ética) do agir sobre o pensar leva obviamente a que se pense mal, ou nem se pense, e se atue muito mal.

Pode, evidentemente, ser-se eficaz na ação. Estabelecendo-se uma meta, chegar-se a ela. Com uma cega fidelidade ao Chefe, estamos perante situações em que, nada se discutindo (como em um célebre discurso de Salazar), se podem concentrar esforços e vontades para, então, atingir objetivos. O problema é o sentido profundo dessa ação. A eficiência concreta encerra, porém, no horizonte geral da ação, uma inquinação porque o objetivo é perversamente antiético e os meios são também de mão de ferro.

\subsection{UNANIMISMO}

“Quem não é por nós é contra nós". Em um horizonte de férreo unicitarismo, 
Populismo \& preconceito: clarificando questões ideológicas e jurídicas de um vírus político, em diálogo com Umberto Eco

obediência cega, cadavérica, ao chefe, todo o pluralismo ${ }^{5}$ e toda a distinção é uma quebra na unidade e uma traição. Não pode haver a mínima falha de fidelidade ao Chefe, à mística instituída: nem por leve tentação de pensamento. Tal ação leva, necessariamente, às vagas de depuração. Os amigos de ontem passam a ser, pela mais leve discordância (ou pela paranoia do Chefe, que neles vê potenciais traidores, ainda que nada tenham feito de suspeito), inimigos mortais de hoje. Esses tipos de regimes totalitários (que não são características privativas do fascismo) estão fadados à, permanente, depuração, e o poder acaba por ser a solidão das solidões.

\subsection{MEDO DA DIFERENÇA}

Em decorrência do medo, do pânico do referido unanimismo, tem-se como consequência lógica a negação do outro. Por isso, há o racismo, diz Eco, mas não só o racismo: também tudo o que é diferença. Toda a discrepância do retrato-robot, do modelo da perfeição (os "nós"), refere-se à negação e / ou à tentativa de abolição de todos os "outros" ou à subjugação, como seres ontologicamente inferiores.

\subsection{FRUTO DA FRUSTRAC̣ÃO}

O fascista é, em geral, um frustrado, um recalcado, um "perdedor", pessoal e socialmente. Mesmo que aparentemente tenha subido muito, há sempre uma privação que o macula mortalmente, pela qual transporta uma mágoa que se transforma em raiva e sede de vingança.

Assim, procura compensar a miséria da sua vida em uma catarse de força que não tem pessoalmente, de violência, que individualmente não poderia exercer, dando largas aos seus fantasmas e às suas fantasias de poder, exaltação, autoglorificação e vingança. Daí os bodes expiatórios que se consideram responsáveis por seus males. Judeus e maçons, por supostamente serem ricos e poderosos manobradores, uns mais da finança outros mais da política; estrangeiros e de outras "raças" por alegadamente lhes ficarem com os empregos; comunistas por representarem a possibilidade de lhes vir a ser tirado pelo Estado o pouco (ou muito) que têm; homossexuais, que representam a subversão da rígida moral em que foram mantidos, e outros mitos urbanos (e não só urbanos) do gênero.

A classe média ou proletários que ascenderam a uma baixa classe média, com seus sonhos e frustrações por não alcançarem o padrão de consumo e consideração social dos que se encontram acima, e muito acima, são potencial (e já real em alguns

\footnotetext{
${ }^{5}$ Sobre a importância do pluralismo na democracia, v. Todorov (2017, p. 15 ss..).
} 
lugares) clientela do fascismo de hoje, acreditando estultamente que ganharão alguma coisa com isso. A desilusão será muito rápida, mas o fascismo tem o grave problema de não se conseguir emendar nem rápida nem facilmente. Pelo que os culpados por um triunfo de qualquer fórmula nem sequer dele aproximada, depois de um breve estado de graça, de um momento de negacionismo, e ainda de tempo de pretensa justificação do injustificável, começarão a duvidar, a duvidar, até que se sentirão traídos, contudo será tarde demais.

\subsection{NACIONALISMO E TEORIA DA CONSPIRAÇÃO (INTER)NACIONAL}

O fascista e o seu partidário precisam permanentemente sentir o inimigo latente, o perigo latente, normalmente, o estrangeiro, as potências estrangeiras ou quintas colunas. Por esse motivo, os bodes expiatórios são também grandes grupos internacionais ou internacionalizados: judeus (sionismo internacional), maçonaria (pedreiros livres internacionais), comunistas (o célebre e temível "comunismo internacional" de que tanto falava a propaganda salazarista), a que podem também associar-se socialistas e afins (nesse caso, dir-se-á o "socialismo internacional", confundindo o pacato social-democrata com o mais extremista dos maoístas ou trotskistas). Ao nível interno, certamente pode haver tiques dessa mania com o chamado "lóbi gay", e não é impossível que não possa haver estigmatização de outros grupos ascendentes, como o do "feminismo", que também é internacional.

\subsection{O INIMIGO É FORTE E É FRACO}

Há uma propaganda que, ao mesmo tempo, galvaniza e confunde os próprios fascistas, incapazes de verem com clareza os seus inimigos. Aliás, o fascismo é a grande ilusão e autoilusão (nisso, por exemplo, totalmente diferente, abissalmente, dos vários comunismos, desde sempre habituados a destrinçar até inimigos principais e secundários, objetivos e subjetivos, assim como aliados táticos, estratégicos e históricos).

Assim, por um lado, são prodigiosas a riqueza e a força dos inimigos (os democratas nos seus países "podres" de ricos e, assim, "degenerados", os judeus "avarentos", os assustadores blocos comunistas, com todo o seu aparato bélico e industrial - quando os havia).

Nesse sentido, Eco vaticina que os fascistas, incapazes de avaliar objetivamente os inimigos, estariam fadados a perder guerras. Não seríamos tão otimistas, porque, na guerra, há também o fator da sorte, entre outros, e, hoje, quem está disposto a verter "sangue, suor e lágrimas" pela democracia? Nisso os fascistas têm alguma razão: a fartura 
Populismo \& preconceito: clarificando questões ideológicas e jurídicas de um vírus político, em diálogo com Umberto Eco

relativa (e ultimamente em depauperamento: daí a inquietação) das classes médias das democracias corrompeu-lhes a fibra, despolitizou-as e degenerou-as no sentido de lhes ter diluído as virtudes republicanas ${ }^{6}$. Essas mesmas classes médias, ao primeiro soprar das crises, lá se lançam nos braços do fascismo porque há um punhado de corruptos, mais ou menos, que se apontam como sendo o exemplo dos políticos democráticos. Sim, há muita corrupção (descoberta) nas democracias, mas, nas ditaduras, há muito mais (encoberta). São estórias que deveriam ser bem conhecidas, mas não o são, pela falência educativa das democracias.

Apesar da propaganda dos burocratas da educação (que embandeiram em arco com estatísticas para inglês ver e competências meramente técnicas, como as bases da informática "na ótica do utilizador"), a grande falência das democracias reside precisamente em uma massificação sem alma, sem real democratização, que escraviza os docentes em estatísticas e papeladas, bem como distribui diplomas (como o feiticeiro de $\mathrm{O} z^{7}$ ) sem rigorosa avaliação (às vezes, sem nenhuma), mas não tem sido capaz de verdadeiramente elevar as pessoas comuns. Ilude-as, dando-lhes miragens do saber, mas não as prepara com cultura, nem com sentido crítico, nem com ética republicana, que seriam as armas contra o canto das sereias antidemocráticas. Isso porque povos verdadeiramente educados não se deixam iludir por populismos.

\subsection{EXALTAÇÃO DA GUERRA}

Para o fascista, a vida é uma guerra permanente, e proliferarão as guerras até à batalha final. Eco observa bem que, depois do pretenso triunfo final do fascismo, não poderia haver mais guerra. Contudo, espera-se que esse problema nunca se venha a colocar na prática.

Do lado democrático, a Paz é o objetivo, mas, desde que, pelo menos, os Romanos que sabemos se consolidem a Paz precisamente preparando-se para a guerra. No nosso caso, pelo poder persuasivo da força das democracias e dos democratas: si vis pacem para bellum (atribuído a Flávio Vegécio). Mais tarde, tentou-se doirar a questão com uma alteração substancial do adágio: si vis pacem para pacem. No limite, poder-se-á dizer que tal brocardo também é verdadeiro, conquanto não se esqueça de que a paz se prepara estando atento e preparado para a eventualidade de uma agressão.

De tal modo, pode também nem sempre ser o elogio da guerra internacional o concreto discurso do fascista agora ou logo, pode ser o afrontamento interno e a luta ou

\footnotetext{
${ }^{6}$ Cf. os nossos livros Nova Teoria do Estado. Estado, República, Constituição (CUNHA, 2013) e Para uma Ética Republicana (CUNHA, 2010).

${ }^{7}$ Baum (1995). E o filme The Wizard of Oz (1939).
} 
caça a certos grupos. Primeiro se começará até pela caça aos tubarões, aos capitalistas mesmo, aos corruptos, evidentemente, ou a criminosos mais hediondos, para quem se proporá pena de morte, tortura, castração, campos de concentração etc. Diante disso, alarga-se-ão os grupos até pela confusão de conjuntos. Assimilar-se-ão, por exemplo, algumas minorias étnicas ao crime, outras à finança, à corrupção, à exploração (se o populismo em causa quiser apostar num lado "anticapitalista”, o que, porém, pode desagradar a alguns apoiantes endinheirados e até eventuais financiadores) etc.

Como no célebre poema do Pastor Niemöller: "primeiro vieram pelos comunistas"...

\subsection{ELITISMO DE MASSAS}

É muito interessante este ponto, que tem aspectos simétricos ou pontes com a questão da tradição. O fascismo é evidentemente reacionário, e isso o levaria a um aristocratismo, mas é apoiado pela boçalidade plebeia, que, por seu turno, não suporta a distinção e o esnobismo dos aristocratas (ainda que, com o tempo, muitos sejam uma simples caricatura dos de outras épocas - com, muito menos, distinção e, muito mais, esnobismo).

Por outro lado, os novos dirigentes desses grupos raramente são de linhagem aristocrática, e, na dinâmica da progressão populista, acabará por tornar-se necessário erradicar esse grupo de gente, que, aliás, em geral, despreza os fascistas em absoluto (pode haver sempre nas hostes fascistas, tem havido um ou outro nobre oportunista adesivo ou seduzido pela mística anticomunista etc. - mas não é a regra, é mesmo uma espécie de "traição de classe"). No limite, os constrangimentos éticos e estéticos de um aristocrata, ainda que muito decaído, não conseguirão suportar as alarvidades da boçalidade demagógica ou a frieza amoral (imoral) do tecnocratismo. O choque está previsto, e a colisão apenas adiada.

Promete-se, portanto, a qualquer plebeu ativista fascista a ascensão e uma espécie de nobilitação (por heroicidade e fidelidade fascista), mas é óbvio que, de degrau em degrau do escalão, cada um despreza e humilha o inferior hierárquico. Há uma estrutura piramidal rígida, e a ascensão é, como, aliás, sempre é raríssima e fortuita, porém, mais que elitismo, talvez se deva sempre dizer oligarquia. A clique dirigente dos fascismos é oligárquica, e o uso das massas nem sequer é absolutamente original em si.

Há, no fascismo, um aproveitamento de técnicas de propaganda e transmissão, bem como de sedução psicológica novas, no entanto os reis taumaturgos (BLOCH, 1983) medievais faziam milagres públicos, e, ainda hoje, entre os monárquicos, há a crença na ligação íntima do povo ao rei como no fascismo do povo ao Duce ou ao Führer. 
Populismo \& preconceito: clarificando questões ideológicas e jurídicas de um vírus político, em diálogo com Umberto Eco

\subsection{PSEUDOHEROICIDADE E PSEUDOMARTÍRIO DO MILITANTE COMUM}

Todo fascista seria um herói e um potencial mártir, o Viva la muerte, de MillánAstray, é um exemplo disso. Cada adolescente incorporado nas fileiras nazistas era convencido de que poderia ser um herói ou um herói-mártir, talvez, mais nobre ainda. É o complexo kamikaze.

Caso se despreze a própria vida, claro que milhões de judeus e outros bodes expiatórios, nos fornos crematórios, não são nada até porque eles nem seriam verdadeiras pessoas... No desprezo quotidiano do fascista ou ainda protofascista que, em uma conversa de café, deprecia o muçulmano migrante, o nordestino do Brasil, o alentejano em Portugal, acha-se que as pessoas feias não devem ter emprego como os outros ou que as mulheres devem ganhar menos porque engravidam (ou simplesmente porque seriam "inferiores"), além de tantos outros tiques que, por desatenção, pressa e laxismo, vamos tolerando (e essas coisas são intoleráveis). Então, ocorre em potência a possibilidade de se vir a prescindir desses pesos mortos, desses incômodos, desses estorvos. Já se podem ler intelectuais a propor que se encostem ao paredão uns ou outros. Sim, começa-se pelos corruptos e pelos criminosos de crimes de sangue ou de escândalo sexual... mas depois... faites encore un effort...

Isso ocorre porque apelar para punições exemplares a pessoas que o público considera monstros é, evidentemente, popular, e, caso se pense assim, todos os corruptos deveriam ser executados - todos os banqueiros seriam considerados corruptos todos os banqueiros seriam judeus - logo, todos os judeus se tornariam corruptos e mereceriam ser executados. Ainda que não sejam banqueiros, claro, e muito menos corruptos...

Com essas abordagens, não se está obviamente a defender corruptos, e os banqueiros, em si, parecem não precisar, por enquanto, pelo menos, de quem os defenda. Os judeus sim, pois, de novo, se veem atacados até nos seus túmulos, assim como muitos outros grupos, por exemplo, muçulmanos, maçons e até católicos. Isso depende dos locais e das ocasiões, enquanto outros, sempre. Alguns desses ataques, só na atualidade, são mais visíveis, entre eles contra negros pobres, mulheres pobres e homossexuais pobres, por exemplo, e contra ciganos, em geral, por sempre serem considerados pobres, o que depende das latitudes. Em uns, os alvos são mais uns do que em outros porque depende das vulnerabilidades e da especialização dos preconceitos.

Podemos tentar outros exemplos, igualmente perigosos, com outros grupos. 


\subsection{ERSATZ DA GUERRA: SEXISMOS}

Há uma transferência sexual da guerra. A tradução de Eco fala em vontade de potência (ou será simplesmente de poder, mais próximo do sentido normal que se dá a Nietzsche?). Daí decorre a proscrição ou pelo menos o preconceito contra o que não se possa identificar com a figura do herói masculino tipo. Donde decorre a misoginia e os "hábitos menos conformistas", que vão da homossexualidade à castidade (contudo pelo menos aprovada nos sacerdotes ou monges e monjas das religiões que, para si, a requerem). A padronização e a aferição por um modelo de "macho alfa" parece ser a regra, embora, devido a vários recalcamentos e espírito de vingança, possa haver membros de minorias a aderir ao populismo e até ao fascismo com a esperança de triunfar e fazer pagar aos que o/a humilharam, exploraram etc.

\subsection{POPULISMO, ANTIPARLAMENTARISMO}

Há muito a refletir e a extrair da frase de Álvaro de Campos, na Ode Triunfal, segundo a qual um parlamento é tão belo como uma borboleta. Essa beleza só é apercebida por alguns. Mesmo no campo democrático, há muita cegueira a tal imagem.

Por um lado, são as cores plurais da borboleta. Por outro, ela não surge imediatamente. Precisa de tempo e maturação para passar ao estádio de borboleta.

De qualquer forma, os fascistas odeiam a democracia, o pluralismo, e a sensitiva (talvez uma das politicamente mais expressivas dessa ideologia tão metamórfica, afinal, e que se dedica tanto a esconder-se e exdenominar-se ${ }^{8}$, quando em democracia plena e pujante) desse ódio é a proclamação antiparlamentar.

Não é privativa dos fascistas. Oliver Cromwell também vociferava ódio em pessoa no próprio parlamento, que fez fechar. $O$ antiparlamentarismo é típico de toda ditadura, de toda tirania. Mas o fascismo doira esse ódio com uma justificativa pseudomoral, pseudoética: no parlamento estaria o covil dos ladrões, dos corruptos etc. Precisamos, assim, de ter o maior cuidado e exercer uma pedagogia cívica inteligente com quantos acreditam piamente nesse mito-mistificação.

Evidentemente que, nos parlamentos, como em todas as proximidades de poderes (e não só políticos, antes de tudo nos que mexem mais com dinheiro, os financeiros e econômicos), é natural que haja a normal cota de corruptos. Faz certamente parte da natureza humana um nível relativamente razoável de vícios. Mas do que se trata, proverbialmente, neste caso, é de estigmatizar o parlamento desacreditando os parlamentares. Apesar disso, mesmo em situações de muita corrupção, não será mais

\footnotetext{
${ }^{8}$ Cf. Barthes (1978).
} 
Populismo \& preconceito: clarificando questões ideológicas e jurídicas de um vírus político, em diálogo com Umberto Eco

do que meia ou, com boa vontade, uma dúzia de nomes que se aventarão concretamente suspeitos. A pergunta fundamental é: quantas condenações houve? Logo vem novo argumento: o poder judicial, a polícia etc. são coniventes, são cúmplices. Quiçá porque infiltrados por esta sociedade secreta, aquele partido, aqueloutra religião, ou a "raça" X ou Y etc. O é círculo vicioso.

A questão é muito interessante. Se um parlamento passa a ser fascista (como ocorreu com a Assembleia Nacional portuguesa, que só em fim de vida teve efêmera e escassa "ala liberal" não concordante, e mesmo assim eleita nas listas da "Situação" - e que em parte se foi demitindo: recordemos nomes, como os de Miller Guerra e Sá Carneiro) muda a sua índole, e os que eram, pela essência do parlamentarismo, corruptos por natureza, passarão a ser impolutos pela nova natureza do contexto ditatorial? Só o parlamento livre é que é corrupto? Um parlamento com Yes men passa a ser virtuoso? Se não, por que não há a coragem de totalmente prescindir dessas assembleias ditas (quando em democracia) de puros palradores ociosos e nocivos? O hemiciclo dito das negociatas passa a um areópago de anjos ou de santos?

\subsection{UMA NOVILÍNGUA}

Não se trata apenas de um léxico elementar, muito pobre, ou mesmo de calão agressivo e redução de coisas complexas a metáforas pueris - tudo isso comprime a capacidade de pensar e de sonhar. Há muito mais nessa língua nova (importamos, claro, o termo de George Orwell, mas não seguimos a tradução portuguesa de Eco, antes a de velhas traduções da obra daquele, 1984).

Eco é muito eloquente ao evocar o que ocorreu com a leitura dos jornais quando (era ele criança) o fascismo caiu em Itália. Desde logo, pela primeira vez, ouvia falar em "liberdade" e "ditadura". Contudo, esta habilidade protetora do fascismo fará que, em 1991, se haja constituído de novo em Itália um movimento "Fascismo e liberdade", ou "partido nacional socialista". Eis como se manipulam as palavras pro domo, perante a inação dos poderes e dos movimentos que aparentemente deveriam defender a democracia e a palavra no seu sentido real. Confúcio estava certíssimo quanto à primeira coisa a fazer para a saúde e a sanidade de um Estado: retificar a linguagem".

Do mesmo modo, vejamos um exemplo prático. Se um cônjuge ou namorado que mata o outro (o "normal" nas nossas sociedades tem sido que seja um homem a matar uma mulher, mas pode haver todas as variantes possíveis) diz que o faz por amor, em princípio, não será acreditado. Há uma chocante contradição no seu argumento.

\footnotetext{
${ }^{9}$ CONFÚCIO - Lun-yu, ou Analectos, XIII, 3. Cf., v.g., Confucius (1981, p. 102); Comentários, v.g. in Leys (2009, p. 66). (CHENG, 1997, p. 82 ss..).
} 
Ora, um fascista hoje também não se faz acreditar quando diz que é democrata ou defende a liberdade. Acontecem muito ambas as coisas. No entanto, apesar de tudo, só um machista como um assassino acreditará neste tipo de argumento, ainda há alguns democratas sem mãos e com o pensamento cristalizado que se sentem embaraçados por, no seu íntimo, saberem que há fascistas à solta e a criarem organizações, partidos, e a disputarem eleições, iludindo o povo, contudo continuam a dizer-se democratas. Os democratas sem mãos e sem decisão acreditam que as pessoas, todas as pessoas devem ser julgadas pelo que dizem. Esquecem que pode haver enorme diferença entre o que vão dizendo, para iludir os incautos, e os seus planos, contudo revelados por indícios claros. O que interessa são os frutos das árvores ${ }^{10}$. Para a deteção precoce destes, é preciso ver as sementes. Estas são de violência, ódio, discriminação, enfim, tudo o que vimos como indícios do "fascismo eterno".

Esperam os democratas sem mãos e sem prudência pelas maiores agressões. Sentem-se até muito incomodados no seu conforto quando alguns mais se alertam e alertam os demais. Acham invariavelmente que são alarmistas e, no fundo, temem que sejam “comunistas"... A verdade é que muitos também desprezavam o Coronavírus como uma gripe qualquer asiática, e veio a dar o que já veio a dar, e o que pode ainda dar...

Com o tempo, uma vez instalado o fascismo no poder, cria-se um efeito mimético muito forte, e as pessoas que não aprendem o novo léxico, a nova sintaxe, os novos tópicos (que não os adotam nem absorvem com alguma "naturalidade") são excluídas e sentem-se como marcianos, em um outro mundo. Quem, no seu são juízo, pode dizer "Heil Hitler!" como cumprimento habitual? É o que pensamos felizmente hoje, em democracia (ainda). Mas a habitualidade da alarvidade do dito era evidente no seu tempo e lugar. As pessoas certamente já não estranhavam e sempre repetiam.

Evidentemente, as palavras criam realidades, é por isso que, da banda contrária ao fascismo (alguns acham que em certos casos se trata de variantes menos clássicas de fascismo) se luta por redefinir coisas, situações, relações, por via de palavras novas ou novo uso de antigas. Há, em curso, uma guerra linguística terrível, em que é difícil manter neutralidade, mesmo quando, moderadamente, crê-se que a língua deveria ser uma espécie de terreno de consenso, de território de paz entre as aguerridas ideologias hoje em conflito. Porém, como se trata de contendores muito aguerridos, agressivos e intolerantes, que só aceitam a vitória total ou a morte (e esta não a aceitam realmente), é complicada a situação de não se ser nem de um lado nem do outro. Ambos os grandes grupos excomungarão quem não tome o seu partido.

Mas insista-se. A novilíngua serve não só a um totalitarismo quando o fascismo

${ }^{10}$ Lc. VI, 44. 
Populismo \& preconceito: clarificando questões ideológicas e jurídicas de um vírus político, em diálogo com Umberto Eco

está no poder: é um instrumento da sua absolutização, mas também um instrumento da política de mentira que permite conquistar incautos, "idiotas úteis". Nesse mesmo ponto, Umberto Eco explicitamente nos adverte para o fato de que o novo fascismo, os novos fascismos poderão não vir embrulhados na mesma embalagem que historicamente conhecemos: camisas negras (ou castanhas, ou azuis, diríamos nós), paradas, etc. (ECO, 2018; ECO, 2016, p. 39).

Portanto, não podem agir de boa-fé os juristas e as autoridades que, prevenidas há muito tempo para o lobo com pele de cordeiro (embora deixando escapar alguns tiques de lobo, evidentemente), encolham os ombros ou se digam de mãos atadas perante o crescimento da propaganda do fascismo, com a alegação de que não viram suásticas, não vislumbraram camisas negras, não escutaram ou leram a palavra "fascismo", nem sequer a glorificação de Salazar, Hitler, Franco ou Mussolini (e outras figuras menos conhecidas entre nós), e, pelo contrário, viram protestos de fidelidade democrática e até respeito pelos Direitos Humanos.

Claro que há um calcanhar de Aquiles nesta deteção do fascismo baseada em evidências... É que, se levada perversamente ao extremo, poderiam ser etiquetados de fascistas grupos que não o são. Por exemplo, já se está a pensar em que uma sutil pirueta poderia passar a chamar fascistas a grupos de esquerda (afinal, o partido nazi não era "nacional socialista"?). Atrevemo-nos a pensar que o extremismo de esquerda, hoje, é uma válvula de escape residualíssima (afinal útil à democracia, na medida em que afirma a sua pluralidade), e, evidentemente, se algum desses grupos enveredasse pela infração às regras da legalidade democrática, não haveria certamente qualquer imunidade que o salvasse da mão pesada da lei.

Porém não ocorrerá o mesmo com o fascismo? É completamente diferente. Se mais razões não houvesse, porque o fascismo é efetivamente um perigo real para a democracia, enquanto esses grupos radicais são (pelo menos por ora, mas crê-se que por muito tempo) um resíduo do passado. O fascismo ganha eleições. Esses grupos nunca alcançam mais que um ou dois por cento, mesmo concorrendo, muitas vezes, em frentes e coligações. Frequentemente se fazem e desfazem em quezilias intermináveis do tipo das excomunhões entre seitas e acabam por ser inofensivos à democracia. Em certos casos são até o seu sal e pimenta, não deixando certas causas esmorecer. Obviamente, tudo seria diferente se constituíssem um real perigo para as instituições democráticas - o que não se vislumbra em nenhum país democrático...

Finalmente, um argumento positivista, tão do agrado dos juristas sem mãos. A Constituição portuguesa não fala senão em proscrição hoc sensu de racistas e fascistas, não em outros. Por muitas voltas que se dê à ideologia, não haverá tratos de polé que transformem um esquerdista (desses que, segundo Lenine, sofreriam da "doença infantil 
do comunismo" - um extremista de esquerda) (LENINE, 2019) em um fascista. Tenhamos respeito pelas palavras e pelas ideologias. Aliás, um fascista que se prezasse (e conseguisse superar o tacticismo - se fosse possível) não suportaria ser colocado a par de um desses esquerdistas.

\section{BREVIISSIMA CONCLUSÃO JURÍDICO-SOCIOLÓGICA}

Não se trata de considerar o fascismo e os fascistas, evidentemente, apenas no sentido purista histórico, para o qual só os do tempo e do partido de Mussolini o seriam, mas de pensar no sentido que interessa, atualista e atualizado.

O sentido que buscamos hoje, e não é empresa isolada, mas muito glosada e com enorme interesse prático (pois da deteção do fascismo e dos fascistas depende a sobrevivência das democracias), é o da descoberta de quem será capaz, por sinais evidentemente já manifestados, de promover políticas de ódio, rancor, massacre, discriminação, extermínio, de subverter os regimes democráticos instituídos, por perfilhar ideias e preparar ações em tudo semelhantes às dos fascismos históricos e seus congêneres.

Trata-se não de punir ideias, de sufocar a liberdade de pensamento e de coartar as liberdades de expressão, reunião, associação etc., mas de uma justa autodefesa do regime democrático, que precisa de preservar o seu pluralismo. Ora, os fascistas usam o pluralismo como meio de ascender ao poder, mas (obviamente, pela sua própria natureza) não o permitem quando no poder se encontram. Se for preciso excluir os fascistas do jogo democrático nada se perde (nem sequer uma pretensa pureza de liberdade mesmo para os inimigos da liberdade), porquanto muito se ganha: quantos não são os que os fascistas torturarão, matarão, ilegalizarão etc.?

Parece estranho ter de escrever estas linhas, porque deveria ser algo óbvio. Contudo, as democracias, muito fiadas na auto evidência da sua superioridade, pouco curam de formar a favor dos seus princípios, e quanto mais as ditaduras a que se sucederam se tornam distantes no tempo, mas os jovens não entendem o que se passou e alguns, mesmo devidamente doutrinados pelos candidatos a ditadores, até acalentam ilusões quanto a esses tempos passados que foram terríveis. A falta de conhecimento histórico é profunda, crescente e criminosa por parte de políticas educativas laxistas e pretensamente modernas, que não dotaram os cidadãos de armas ideológicas eficazes para exercer o sentido crítico que se impõe contra os cantos de sereia populistas, semente de fascismo, pelo menos.

Trata-se, assim, de ver as mãos de quem podem as democracias perecer.

Vejamos o que diz a Constituição sobre o problema. Embora, no seu entusiasmo 
Populismo \& preconceito: clarificando questões ideológicas e jurídicas de um vírus político, em diálogo com Umberto Eco

de recém-derrubamento do regime fascista, os constituintes tenham sido, muito natural e compreensivelmente, não excessivamente precavidos. É também a magnanimidade típica dos grandes vencedores.

Há poucas referências explícitas no texto constitucional ao fascismo. Mas são tão eloquentes que basta citar: o único sentido útil que podem ter tanto a referência ao derrube do regime fascista no início do Preâmbulo da Constituição da República Portuguesa, como a prescrição de proibir organizações que perfilhem a ideologia fascista (art. 46, n. ${ }^{\circ}$ ), é um sentido dinâmico e não histórico.

Pela existência de ambos esses momentos da Lei Fundamental, vemos que um fascismo tanto existiu em Portugal antes do 25 de abril de 1974 (não é do regime italiano de Mussolini que se trata, é mais que óbvio), como o fascismo poderá vir a ser perfilhado no futuro, e, por isso, desde logo se proíbe. Não deixa de ser muito importante esta realidade que se extrai com hermenêutica literalíssima da nossa Lei das Leis. Não há como subvertê-la. Nem o revisionismo histórico poderá dizer que não houve fascismo antes da revolução de abril, nem o fundamentalismo historicista poderá querer amarrar o fascismo a uma época passada apenas. Não: houve-o no passado português, bem datado e pode voltar a existir no futuro.

A ideologia fascista tem um sentido que se identifica, em boa medida, com a lista de preconceitos que brevemente referimos. Ser fascista é, hoje, ter os preconceitos, os antolhos, as crenças, os mitos-mentira, a ideia-força e o discurso legitimador (todos os grandes sentidos de "mito" ${ }^{11}$ ) referidos no texto supra, e porventura alguns mais, que possam ter escapado.

Mas o fascista deteta-se ao longe, pela sua segurança desafiadora, um tanto boçal, muitas vezes, pelos seus modos abruptos, pela sua inflexibilidade, pela sua agressividade, pela sua incomodidade visceral em viver em paz com os outros, pelo seu desprezo pela Lei. É matraqueador, é intrusivo, é maledicente, é mentiroso, é monomaníaco, é vaidoso, é intempestivo, é impetuoso, é egocêntrico, é rompante, é narcísico, é grosseiro, fere a inteligência, a sensibilidade, o bom gosto e o bom senso. Claro que, num caso ou noutro, poderá vir mais com pés de lã ou com um paradoxo até inteligente. Os casos,porém, são raros. O pano de fundo é o da preparação do terror.

Insistamos, para que não haja dúvidas, claro, que há raríssimos que dissimulam, razoavelmente, e podem até parecer moderados, cultos, refinados. Mas, em alguns minutos de conversa, normalmente desmascaram aquele que nos quer privar de direitos, liberdades, garantias e instituir uma ordem de terror, em proveito apenas de si e dos seus. Ou nem isso sequer, se for um homem ou mulher de mão, iludido também, peça da engrenagem da barbárie.

\footnotetext{
${ }^{11}$ Cf., por todos, Girardet (1986). E ainda Mucchielli (1980); Reszler (1981).
} 
Eles estão no meio de nós. É só olhar em volta ${ }^{12}$. E não assobiar para o lado.

\section{REFERÊNCIAS}

BARTHES, Roland. Mitologias = Mythologies. Tradução José Augusto Seabra. Lisboa: Edições 70, 1978.

BAUM, L. Frank. The Wonderful Wizard of Oz. Londres: Penguin, 1995.

BLOCH, Marc. Les rois thaumaturges: Etude sur le caractère surnaturel attribué à la puissance royale particulièrement en France et en Angleterre. Préface de Jacques Le Goff. Paris: Gallimard, 1983.

CHENG, Anne. Histoire de la Pensée Chinoise. Paris: Seuil, 1997.

CLINCHAMPS, Du Puy de. Le Snobisme. Paris: PUF, 1964.

CONFUCIUS. Entretiens de.... Tradução do chinês de Anne Cheng. Paris: Seuil, 1981.

CUNHA, Paulo Ferreira da. Raízes da República: introdução Histórica ao Direito Constitucional. Coimbra: Almedina, 2006.

CUNHA, Paulo Ferreira da. Para uma Ética Republicana. Lisboa: Coisas de Ler, 2010.

CUNHA, Paulo Ferreira da. Nova Teoria do Estado: Estado, República, Constituição. São Paulo: Malheiros, 2013.

ECO, Umberto. Cinco Escritos Morais = Cinque Scritti Morali. Tradução José Colaço Barreiros. Lisboa: Relógio de Água, 2016.

ECO, Umberto. O Fascismo Eterno. Rio de Janeiro: Record, 2018.

GIRARD, René. Le Bouc Emissaire. Paris: Grasset, 1982.

GIRARDET, Raoul. Mythes et mythologies politiques. Paris: Seuil, 1986.

12 O problema é que, evidentemente, as pessoas que apresentam os sintomas aqui descritos, nem todas se afirmarão fascistas ou sequer populistas. Numa situação como a atual, é muito provável que muito poucas se afirmem como tal (mas tal não será o caso se essas forças começarem a crescer). E pode ser que levem a mal ser assim consideradas. Mas o que fazemos, na senda de Umberto Eco, não é senão um trabalho de taxonomia, de classificação. Nada mais. Apresentamos um espelho para as pessoas verem o fascista que há nelas e para que a sociedade se veja com os traços de fascismo que mesmo uma democracia pode ter. Mas não confundamos as coisas: de um lado, temos aspetos autoritários, totalitários e afins numa sociedade e numa pessoa, em termos gerais alinhadas pela democracia; de outro, a psicologia do fascista. A grande questão é de saber até que ponto se pode ser fascista sem o saber. 
Populismo \& preconceito: clarificando questões ideológicas e jurídicas de um vírus político, em diálogo com Umberto Eco

LENINE, V. I. U. Esquerdismo, doença infantil do comunismo. Disponível em: https://www.marxists.org/portugues/lenin/1920/esquerdismo/index.htm. Acesso em: 7 abr. 2019.

LEYS, Simon. (dossier coordenado por Minh Tran Huy). De -551 à Aujourd'hui. Confucius les voies de la sagesse. Le Magazine Littéraire, n. 491, p. 66, nov. 2009.

MUCCHIELLI, Roger. Le Mythe de la cité idéale. Paris: P.U.F., 1980.

RESZLER, André. Mythes politiques modernes. Paris: P.U.F., 1981.

RIEMEN, Rob. O Eterno Retorno do Fascismo = De eeuwige terugkeer van het fascisme. Tradução Maria Carvalho. Lisboa: Bizâncio, 2012.

RISO, Walter . A Arte de ser Flexível: de uma mente rígida a uma mente livre e aberta à mudança $=\mathrm{El}$ Arte de ser Flexible: de una mente rígida a una mente libre y abierta al cambio. Tradução Marcelo Barbão. Porto Alegre: L\&PM, 2018.

THE WIZARD of Oz. Direção de Victor Fleming. USA: Metro-Goldwyn-Mayer, 1939. 1 fita de video (101 min), son.

TODOROV, Tzvetan. Os Inimigos Íntimos da Democracia = Les Ennemis Intimes de la Démocratie. Tradução Pedro Elói Duarte. Lisboa: Edições 70, 2017.

WEIL, Simone. O Enraizamento: Prelúdio a uma Declaração dos Deveres para com o Ser Humano = L'Enracinement: Prélude à une declaration des devoirs envers l'être humain. Lisboa: Relógio D'Água, 2014.

\section{Como citar este documento:}

CUNHA, Paulo Ferreira da. Populismo \& preconceito: clarificando questões ideológicas e jurídicas de um vírus político, em diálogo com Umberto Eco. Revista Opinião Jurídica, Fortaleza, v. 18, n, 29, p. 98-119, set./dez. 2020. 